\title{
Effect of Saturated Near Surface on Nitrate and Ammonia Nitrogen Losses in Surface Runoff at the Loess Soil Hillslope
}

\author{
Yu-bin Zhang, ${ }^{1,2,3}$ Fen-li Zheng, ${ }^{2,3}$ and Ning Cao ${ }^{1}$ \\ ${ }^{1}$ Jilin University, Changchun 130062, Jilin, China \\ ${ }^{2}$ Northwest A \& F University, Yangling 712100, Shaanxi, China \\ ${ }^{3}$ State Key Laboratory of Soil Erosion and Dryland Farming on the Loess Plateau, Institute of Soil and Water Conservation, \\ Chinese Academy of Sciences and Ministry of Water Resources, Yangling 712100, Shaanxi, China \\ Correspondence should be addressed to Fen-li Zheng, flzh@ms.iswc.ac.cn
}

Received 17 January 2010; Revised 20 May 2010; Accepted 1 June 2010

Academic Editor: Josiane Nikiema

Copyright ( $) 2010$ Yu-bin Zhang et al. This is an open access article distributed under the Creative Commons Attribution License, which permits unrestricted use, distribution, and reproduction in any medium, provided the original work is properly cited.

Water pollution from agricultural fields is a global problem and cause of eutrophication of surface waters. A laboratory study was designed to evaluate the effects of near-surface hydraulic gradients on $\mathrm{NO}_{3}-\mathrm{N}$ and $\mathrm{NH}_{4}-\mathrm{N}$ losses in surface runoff from soil boxes at $27 \%$ slope undersimulated rainfall of a loess soil hillslope. Experimental treatments included two near-surface hydraulic gradients (free drainage, FD; saturation, SA), three fertilizer application rates (control, no fertilizer input; low, $120 \mathrm{~kg} \mathrm{~N} \mathrm{ha}^{-1}$; high, $240 \mathrm{~kg} \mathrm{~N} \mathrm{ha}^{-1}$ ), and simulated rainfall of $100 \mathrm{~mm} \mathrm{~h}^{-1}$ was applied for $70 \mathrm{~min}$. The results showed that saturated near-surface soil moisture had dramatic effects on $\mathrm{NO}_{3}-\mathrm{N}$ and $\mathrm{NH}_{4}-\mathrm{N}$ losses and water quality. Under the low fertilizer treatment, average $\mathrm{NO}_{3}-\mathrm{N}$ concentrations in runoff water of SA averaged 2.2 times greater than that of FD, 1.6 times greater for $\mathrm{NH}_{4}-\mathrm{N}$. Under the high fertilizer treatment, $\mathrm{NO}_{3}-\mathrm{N}$ concentrations in runoff water from SA averaged 5.7 times greater than that of FD, 4.3 times greater for $\mathrm{NH}_{4}-\mathrm{N}$. Nitrogen loss formed with $\mathrm{NO}_{3}-\mathrm{N}$ is dominant during the event, but not $\mathrm{NH}_{4}-\mathrm{N}$. Under the SA condition, the total loss of $\mathrm{NO}_{3}-\mathrm{N}$ from low fertilizer treatment was 34.2 to $42.3 \%$ of applied nitrogen, while under the FD treatment that was 3.9 to $6.9 \%$. However, the total loss of $\mathrm{NH}_{4}-\mathrm{N}$ was less than $1 \%$ of applied nitrogen. These results showed that saturated condition could make significant contribution to water quality problems.

\section{Introduction}

Water pollution is a major global problem that amounts for more than 14,000 deaths daily [1]. The national environmental statistic bulletin of China reported that total discharge amount of ammonia nitrogen was $127.0 \times 10^{4} \mathrm{t}$ in waste water in 2008 [2]. In the most recent national report on water quality in the United States, 45 percent of assessed streammiles, 47 percent of assessed lake acres, and 32 percent of assessed bay and estuarine square miles were classified as polluted [3].

Phosphorous (P) and nitrogen $(\mathrm{N})$ in runoff from agricultural fields are key components of nonpoint source pollution and can accelerate eutrophication of surface waters $[4,5]$. Most mineral forms of nitrogen are quite soluble in water and may be easily lost from soils through leaching and volatilization. In most freshwater (lakes and streams), $\mathrm{P}$ is the nutrient that can set off eutrophication, and $\mathrm{N}$ is the nutrient most likely to cause eutrophication for saltier waters (estuaries and costal areas) [6].

The transport of agricultural chemicals from the field to groundwater or to surface-water bodies is most commonly facilitated by water movement, and it is affected by rainfall characteristics, underlying surface conditions, and the properties of the soil solute. Hydrogeology, climate, and agricultural management practices can have important influences on the movement of water and chemicals $[7,8]$.

Spatially and temporally variations may affect the dominant erosion processes occurring on the hillslope. During rainfall events, different hydraulic gradients, especially due to seepage or drainage, at different locations on a hillslope profile may have a profound effect on the dominant erosion processes. Recent laboratory studies showed that nearsurface hydraulic gradient had a profound effect in the 
dominant erosion process and total sediment delivery $[9,10]$. Gburek et al. [11, 12] studied results showed that most in-stream $\mathrm{P}$ came from soils within $60 \mathrm{~m}$ of the stream, and Zheng et al. [10] studied results showed that artesian seepage could make important contribution to water quality problems.

Nevertheless, interactions among hydrologic, surface runoff, sediment regimes and $\mathrm{N} \& \mathrm{P}$ losses, and how they are affected by changes in rainfall intensities have not been evaluated extensively in China [13-15]. Based on those studies, the purpose of this study was to examine nitrate and ammonia nitrogen loss of the loess soil in runoff under saturated soil that occurs at $100 \mathrm{~mm} \mathrm{~h}^{-1}$ rainfall intensity. Results of this study will further the understanding of how saturated soil water content impacts the losses of $\mathrm{NO}_{3}-\mathrm{N}$ and $\mathrm{NH}_{4}-\mathrm{N}$ in surface runoff of the loess soil at the hillslope of China.

\section{Materials and Methods}

2.1. Soil Sample Collection. The soil used in this study was a loess soil collected from the surface to a $40 \mathrm{~cm}$ depth at Ansai Country near Yan'an city, Shaanxi province, China. The collected soil was air dried and sieved through a $10-\mathrm{mm}-$ opening sieve and stored in covered concrete floor until used in this experiment.

2.2. Soil Properties. The collected loess soil consists of $64.9 \%$ sand, $23.2 \%$, clay and $11.9 \%$ silt. The soil contains $5.3 \mathrm{mg} / \mathrm{kg}$ organic matter, $0.4 \mathrm{~g} / \mathrm{kg}$ total $\mathrm{N}, 0.6 \mathrm{~g} / \mathrm{kg}$ total $\mathrm{P}$, and $18.2 \mathrm{~g} / \mathrm{kg}$ total $\mathrm{K}$. The content of alkali-hydrolyzadle nitrogen is $32 \mathrm{mg} \mathrm{kg}^{-1}$, while the content of rapidly available phosphorus and potassium is $4 \mathrm{mg} \mathrm{kg}^{-1}$ and $114 \mathrm{mg} \mathrm{kg}^{-1}$, respectively. The water $\mathrm{pH}$ is 8.5 (water/soil ration is $5: 1$ ) and the cation exchange capacity (CEC) is $6.01 \mathrm{cmol}(+) / \mathrm{kg}$.

2.3. Experimental Setup. The study was conducted on three soil boxes that were $100 \mathrm{~cm}$ long, $50 \mathrm{~cm}$ wide, and $40 \mathrm{~cm}$ deep. Each soil box had 18 watering/drainage holes at the bottom. A water supply system was designed to supply water to the soil box from the bottom of the soil box to create the near-surface hydraulic gradient (Figure 1), especially the saturated condition, as described by Zheng et al. [10], and the free drainage condition was created by rainfall.

Two groups of rainfall simulation nozzles, each group with four nozzles, spaced $12 \mathrm{~m}$ apart, were used in this study. The nozzles were approximately $16 \mathrm{~m}$ above the soil surface. During the rainfall simulation, the nozzle pressure was kept at $2.5 \mathrm{~kg} / \mathrm{cm}^{2}$. This rainfall simulator could be set to any preselected rainfall intensities, ranging from 20 to $300 \mathrm{~mm} \mathrm{~h}^{-1}$, by programming the compounding of the nozzles [16].

Experimental treatments in this study included 2 nearsurface hydraulic gradient treatments: saturated condition, and free drainage, and three fertilizer input treatments were subjected to the two soil moisture treatments: control (no fertilizer input, NF), low input (120 $\left.\mathrm{kg} \mathrm{Nha}^{-1}, \mathrm{LF}\right)$, and high

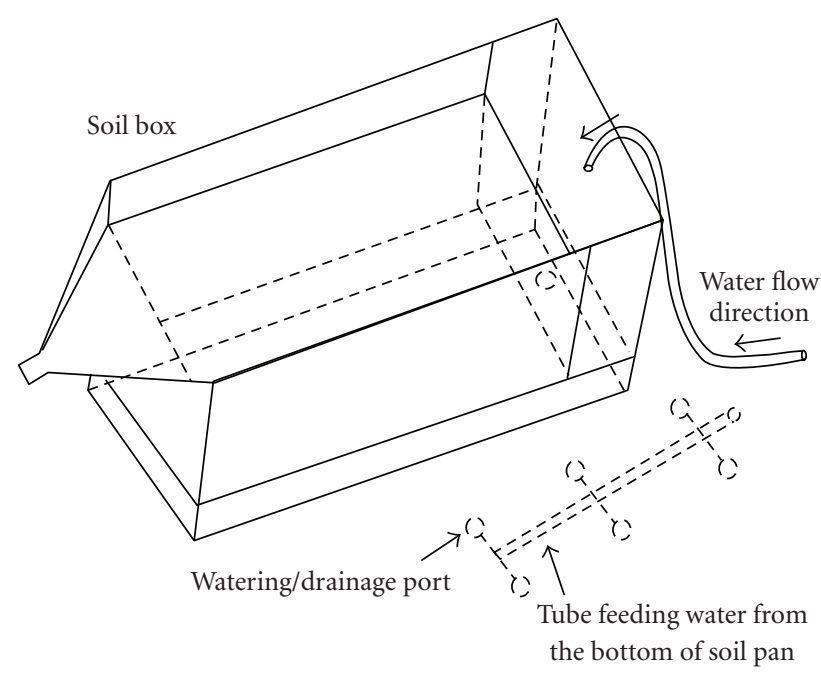

Figure 1: Experiment setup.

TABLE 1: List of experiment treatments.

\begin{tabular}{llc}
\hline $\begin{array}{l}\text { Soil moisture } \\
\text { treatment }\end{array}$ & Fertilizer treatment & $\begin{array}{c}\text { Fertilizer inputs } \\
\mathrm{N} \\
\mathrm{Kg} \mathrm{hm}^{-2}\end{array}$ \\
\hline \multirow{3}{*}{ Saturation (SA) } & Control (NF) & 0 \\
& Low input (LF) & 120 \\
& High input (HF) & 240 \\
Free Drainage (FD) & NF & 0 \\
& LF & 120 \\
& HF & 240 \\
\hline
\end{tabular}

NF, no fertilizer input; LF, low fertilizer treatment/input $\left(120 \mathrm{~kg} \mathrm{Nha}^{-1}\right)$; HF, high fertilizer treatment/input $\left(240 \mathrm{~kg} \mathrm{Nha}^{-1}\right)$. FD, free drainage hydraulic gradient; $\mathrm{SA}$, saturated hydraulic gradient.

input $\left(240 \mathrm{~kg} \mathrm{~N} \mathrm{ha}^{-1}, \mathrm{HF}\right)$. The detailed experimental treatments appeared in Table 1. For each near-surface hydraulic gradient, three replicates were made for rainfall simulation.

2.4. Preparation of Soil Boxes. Each soil box was packed with a $5 \mathrm{~cm}$ layer of sand at the bottom and a $35 \mathrm{~cm}$ depth layer with the air-dried test soil. Moisture content of the test soil was determined prior to packing of the soil box to calculate the amount of soil needed to obtain a bulk density of $1.3 \mathrm{~g} \mathrm{~cm}^{-3}$. The moisture content of the air-dried test soil used for packing soil box ranged from $3 \%$ to $5 \%$ by weight. To ensure uniformity, the soil box was packed in individual $5 \mathrm{~cm}$ layers, and the upmost $5 \mathrm{~cm}$ soil was divided into $3 \mathrm{~cm}$ (below) and $2 \mathrm{~cm}$ (top), and the top $2 \mathrm{~cm}$ soil was thoroughly mixed with $\mathrm{KNO}_{3}$ (AR) as designed [17].

For each layer of soil boxes, the weight of packaged wet soil was calculated by the following equation

$$
W=\rho \times l \times w \times h \times \frac{1+\theta}{100},
$$

where, $W$ is the wet soil weight for packaging in $\mathrm{kg}, \rho$ is soil bulk density in $1.3 \mathrm{~g} \mathrm{~cm}^{-3}, l$ is length of soil boxes in $100 \mathrm{~cm}$, 
$w$ is width of soil boxes in $50 \mathrm{~cm}, h$ is deepness of each layer in soil boxes in cm, $\theta$ is soil moisture content in \%.

After soil box preparation, to further avoid water-dropinduced splash and surface sealing, two layers of gauze were placed over the soil surface. This step was applied to obtain the correct hydraulic gradient, create a uniform surface soil moisture condition prior to the experiment, and reduce surface variability from preparation. After the water supplying, the soil box was covered with a plastic sheet and allowed to equilibrate under each hydraulic condition for 24 hrs.

2.5. Rainfall Experiments. After the water supplying, soil boxes were set to $15^{\circ}$ (approximately 27\%) slope steepness and subjected to the experimental hydraulic gradients. And a simulated rainstorm of $100 \mathrm{~mm} \mathrm{~h}^{-1}$ for 70 min was applied to all treatments based on the result of the basic erosive rainfall standard on the Loess Plateau is $5.8 \mathrm{~mm} / 5 \mathrm{~min}$ [18, 19]. During rainfall simulation runs, runoff samples were collected every $6 \mathrm{~min}$. During each event, the rainfall amount was measured at least twice with two hyetometers around soil boxes to calibrate the rainfall intensity.

Immediately after each run, runoff samples were weighted and set for $24 \mathrm{hrs}$. Water was stored in the plastic buckets in $100 \mathrm{ml}$ and then was analyzed for the contents of $\mathrm{NO}_{3}{ }^{-}-\mathrm{N}$ and $\mathrm{NH}_{4}{ }^{+}-\mathrm{N}$.

2.6. Calculation of Near-Surface Hydraulic Gradient. Soil moisture of the test soil was measured before packed into the soil boxes, preparing for calculating supply water volumes of each near-surface hydraulic gradient, and the volumes were calculated by (2) to control the used-water volumes and save excess water:

$$
W_{s}=W \times 7 \times \frac{M-\theta}{(1+\theta / 100) / 100},
$$

where, $W_{s}$ is water volume of complementarities in $\mathrm{kg}, W$ is wet soil weight for packing in $\mathrm{kg}, 7$ is the layers of soil packaged, $M$ is near-surface hydraulic gradient to control in $\%, \theta$ is soil moisture content of packing soil in $\%$.

2.7. Analysis of $\mathrm{NO}_{3}{ }^{-}-\mathrm{N}$ and $\mathrm{NH}_{4}{ }^{3+}-\mathrm{N}$ in Surface Runoff Water. The collected surface runoff water was set for $24 \mathrm{hrs}$, centrifuged for $10 \mathrm{~min}$ with $8000 \mathrm{r} / \mathrm{min}$ by high speed refrigerated centrifuge (CR21G, Hitachi, Japan), and filtered to test the concentration of $\mathrm{NO}_{3}{ }^{-}-\mathrm{N}$ and $\mathrm{NH}_{4}{ }^{+}-\mathrm{N}$, then all samples were determined by automated chemistry analyzer (Auto analyzer 3-AA3, Bran+Luebbe, Germany).

2.8. Calculation of $\mathrm{NO}_{3}-\mathrm{N}$ and $\mathrm{NH}_{4}-\mathrm{N}$ in Surface Runoff Water. For each simulated precipitation, $\mathrm{NO}_{3}-\mathrm{N}$ or $\mathrm{NH}_{4}-$ $\mathrm{N}$ loss in surface runoff water for the event, $L(\mathrm{mg})$, was calculated by [10]

$$
L=\sum_{i=1}^{n} C_{i} R_{i}
$$

where $L$ is $\mathrm{NO}_{3}-\mathrm{N}$ or $\mathrm{NH}_{4}-\mathrm{N}$ loss in surface runoff water for the event at time increment $i, \mathrm{mg} ; C_{i}$ is concentration in surface runoff water at time $i, \mathrm{mg} / \mathrm{L} ; R_{i}$ is runoff volume at time $i, \mathrm{~L} ; n$ is the total number of collected samples.

For each run, the average $\mathrm{NO}_{3}-\mathrm{N}$ or $\mathrm{NH}_{4}-\mathrm{N}$ concentration in surface runoff water, $C_{n}(\mathrm{mg} / \mathrm{L})$, was calculated as [10]

$$
C_{n}=\frac{L}{V},
$$

where, $L$ is $\mathrm{NO}_{3}-\mathrm{N}$ or $\mathrm{NH}_{4}-\mathrm{N}$ loss, $\mathrm{mg}$; and $V$ is total runoff volume, $L$.

For each soil water content treatment under the same fertilizer treatment, the average $\mathrm{NO}_{3}-\mathrm{N}$ or $\mathrm{NH}_{4}-\mathrm{N}$ concentration in surface runoff water, $C_{m}(\mathrm{mg} / \mathrm{L})$, was calculated as [10]

$$
C m=\frac{\sum_{j=1}^{p} L_{j}}{\sum_{j=1}^{p} V_{j}},
$$

where, $\rho$ is the number of replications in each soil water content treatment, $p=3, L_{j}$ is $\mathrm{NO}_{3}-\mathrm{N}$ and $\mathrm{NH}_{4}-\mathrm{N}$ loss for the event times $j, \mathrm{mg}$, and $V_{j}$ is total runoff volume, $L$.

2.9. Statistical Analysis. The LSD test was performed using SAS (SAS Institute Inc., Cary, NC, USA). Means of each $\mathrm{NO}_{3}-\mathrm{N}$ and $\mathrm{NH}_{4}-\mathrm{H}$ concentration and amount of loss resulting from different treatments were compared for significant difference $(P<.05)$ using Duncan's procedure. In all statistical analyses, a probability level of .05 or less $(P \leq .05)$ was used for significance.

\section{Results and Discussions}

3.1. Concentration of $\mathrm{NO}_{3}-\mathrm{N}$ and $\mathrm{NH}_{4}-\mathrm{N}$ in Surface Runoff Water. The average concentrations of $\mathrm{NO}_{3}-\mathrm{N}$ in surface runoff water were significantly greater than that of $\mathrm{NH}_{4}-\mathrm{N}$ (Table 2). The average concentrations of $\mathrm{NO}_{3}-\mathrm{N}$ and $\mathrm{NH}_{4}-$ $\mathrm{N}$ in surface runoff water of the FD treatments were less than $12.0 \mathrm{mg} \mathrm{L}^{-1}$ and $0.5 \mathrm{mg} \mathrm{L}^{-1}$, respectively, regardless of the fertilizer treatments. When the near-surface hydraulic gradients shifted from FD to $\mathrm{SA}$, concentrations of $\mathrm{NO}_{3}-\mathrm{N}$ and $\mathrm{NH}_{4}-\mathrm{N}$ in surface runoff water increased significantly.

For the control treatment, $\mathrm{NO}_{3}-\mathrm{N}$ concentrations in runoff water of SA averaged 1.8 times grater than that of $\mathrm{FD}$, but it was not statistically significantly difference. Under the low fertilizer treatment, $\mathrm{NO}_{3}-\mathrm{N}$ concentrations in runoff water of SA averaged 2.2 times greater than that of FD. Under the high fertilizer treatment, $\mathrm{NO}_{3}-\mathrm{N}$ concentrations in runoff water of SA averaged 5.7 times greater than that of FD. These results were similar to those reported by Zheng et al. [10]. Under the FD treatment, although $\mathrm{NO}_{3}-$ $\mathrm{N}$ concentrations in the runoff water of the low fertilizer treatment were numerically larger than that of the high fertilizer treatment, concentrations were not significantly different. This is probably the result of less water runoff and better infiltration into the soil.

Concentrations of $\mathrm{NH}_{4}-\mathrm{N}$ in surface runoff water of SA were statistically lower than that of FD, those trends similar to $\mathrm{NO}_{3}-\mathrm{N}$ concentrations in runoff water. For the control treatment, $\mathrm{NH}_{4}-\mathrm{N}$ concentrations in runoff water of SA 
TABLE 2: Means of nutrient concentration with runoff under different near-surface soil moisture conditions.

\begin{tabular}{|c|c|c|c|c|c|c|}
\hline \multirow{2}{*}{ Treatment $^{\dagger}$} & \multicolumn{3}{|c|}{ Concentration in surface runoff } & \multicolumn{3}{|c|}{ Losses in surface runoff } \\
\hline & $\mathrm{NO}_{3}{ }^{-}-\mathrm{N}$ & $\mathrm{NH}_{4}{ }^{+}-\mathrm{N}$ & $\mathrm{NO}_{3}{ }^{-}-\mathrm{N}$ & $\begin{array}{l}\text { Loss as a percentage } \\
\text { of } \mathrm{N} \text { input }\end{array}$ & $\mathrm{NH}_{4}{ }^{+}-\mathrm{N}$ & $\begin{array}{l}\text { Loss as a percentage } \\
\text { of } \mathrm{N} \text { input }\end{array}$ \\
\hline & \multicolumn{2}{|c|}{$\mathrm{mg} / \mathrm{L}$} & $\mathrm{kg} \mathrm{ha}^{-1}$ & \multicolumn{3}{|c|}{$\mathrm{kg} \mathrm{ha}^{-1}$} \\
\hline CFD & $7.94 c^{\ddagger}$ & $0.45 b$ & $7.27 \mathrm{~d}$ & & $0.42 \mathrm{c}$ & \\
\hline CSA & $14.14 \mathrm{c}$ & $0.76 \mathrm{a}$ & $21.11 \mathrm{c}$ & & $1.14 \mathrm{~b}$ & \\
\hline LFD & $11.9 \mathrm{c}$ & $0.46 b$ & $8.28 \mathrm{~d}$ & 6.9 & $0.32 \mathrm{~d}$ & 0.27 \\
\hline LSA & $26.36 b$ & $0.73 a$ & $41.02 \mathrm{~b}$ & 34.2 & $1.14 \mathrm{~b}$ & 0.95 \\
\hline HFD & $11.02 \mathrm{c}$ & $0.17 \mathrm{c}$ & $9.36 \mathrm{~d}$ & 3.9 & $0.15 \mathrm{e}$ & 0.06 \\
\hline HSA & $63.22 \mathrm{a}$ & $0.73 a$ & $101.56 \mathrm{a}$ & 42.3 & $1.18 \mathrm{a}$ & 0.49 \\
\hline
\end{tabular}

${ }^{\dagger} \mathrm{C}$, control fertilizer treatment (no fertilizer input); L, low fertilizer treatment/input $\left(120 \mathrm{~kg} \mathrm{~N} \mathrm{ha}^{-1}\right)$; $\mathrm{H}$, high fertilizer treatment/input $\left(240 \mathrm{~kg} \mathrm{~N} \mathrm{ha}{ }^{-1}\right)$. FD, free drainage hydraulic gradient; SA, saturated hydraulic gradient.

${ }^{\ddagger}$ Mean values with a fertilizer treatment followed by any identical letters are not statistically different at the 95\% confidence level according to LSD tests.

averaged 1.7 times greater than that of FD. Under the low fertilizer treatment, $\mathrm{NH}_{4}-\mathrm{N}$ concentrations in runoff water of SA averaged 1.6 times greater than that of FD. Under the high fertilizer treatment, $\mathrm{NH}_{4}-\mathrm{N}$ concentrations in runoff water of SA averaged 4.3 times greater than that of FD.

Fertilizer application rates influenced $\mathrm{NO}_{3}-\mathrm{N}$ concentrations under the saturation treatment, and the $\mathrm{NH}_{4}-$ $\mathrm{N}$ concentrations in surface runoff water under the FD treatment. Under the SA treatment, both the high and low fertilizer treatments resulted in significantly higher $\mathrm{NO}_{3}-$ $\mathrm{N}$ concentrations than that of the control, increasing by $347.1 \%$ and $139.8 \%$, respectively. $\mathrm{NH}_{4}-\mathrm{N}$ concentrations in the runoff water of the control input to low and high fertilizer treatment were not statistically different. Under the FD treatment, $\mathrm{NH}_{4}-\mathrm{N}$ concentrations in runoff water from control input to low fertilizer input were not statistically different, but that of high fertilizer input was statistically smaller than that of control input and low fertilizer input. It is an interesting question for the results as described above, and no research results could explain the reason, because there were no fertilizers formed with $\mathrm{NH}_{4}-\mathrm{N}$ to soil, and the whole conditions were similar between each soil box and each run, so it is necessary to have a deep research on that. Maybe the fertilizer application rate of $\mathrm{KNO}_{3}$ was the key point for that, and $\mathrm{NH}_{4}-\mathrm{N}$ loss with sediment was the other way for the results above because nutrients formed with $\mathrm{NH}_{4}-\mathrm{N}$ in eroded sediment were enriched compared with topsoil [20,21]. The results above indicated that denitrification had less effect on loss of $\mathrm{NH}_{4}$ $\mathrm{N}$ in surface runoff water in SA treatment in this study.

3.2. $\mathrm{NO}_{3}-\mathrm{N}$ and $\mathrm{NH}_{4}-\mathrm{N}$ Losses. Average losses of $\mathrm{NO}_{3}-\mathrm{N}$ and $\mathrm{NH}_{4}-\mathrm{N}$ displayed similar trends as their concentrations (Table 2). Average $\mathrm{NO}_{3}-\mathrm{N}$ and $\mathrm{NH}_{4}-\mathrm{N}$ losses of the SA treatment were statistically significantly greater than that of FD. $\mathrm{NO}_{3}-\mathrm{N}$ loss in the surface runoff water of CSA was 2.9 times greater than that of $\mathrm{CFD} . \mathrm{NO}_{3}-\mathrm{N}$ loss in the surface runoff water of LSA was 5.0 times greater than that of LFD. $\mathrm{NO}_{3}-\mathrm{N}$ loss in the surface runoff water of HSA was 10.9 times greater than that of HFD. Compared to the CSA treatment, $\mathrm{NO}_{3}-\mathrm{N}$ losses in surface runoff water of the LSA and HSA treatment were 1.9 and 4.8 times greater, respectively. However, under the FD treatment, $\mathrm{NO}_{3}-\mathrm{N}$ losses in the surface runoff water among control, low fertilizer, and high fertilizer input treatment were not significantly different.

Average $\mathrm{NH}_{4}-\mathrm{N}$ loss in surface runoff water from CSA was 2.7 times greater than that of CFD. Under the low fertilizer treatment, average $\mathrm{NH}_{4}-\mathrm{N}$ loss in surface runoff water of SA was 3.6 times greater than that of FD. Average $\mathrm{NH}_{4}-\mathrm{N}$ loss in surface runoff water from HSA was 7.9 times greater than that of LFD. However, under the SA treatment, average $\mathrm{NH}_{4}-\mathrm{N}$ losses of CSA and LSA were not statistically different, although it was statistically different from HSA to LSA and CSA. Under the FD treatment, average $\mathrm{NH}_{4}-$ $\mathrm{N}$ loss of control treatment was statistically greater than that of low and high fertilizer treatments, and it was 1.3 and 2.8 times greater, respectively. The change trend was similar to that as described on concentrations of the part of $\mathrm{NO}_{3}-\mathrm{N}$ and $\mathrm{NH}_{4}-\mathrm{N}$ in Surface Runoff Water in this study.

Under low and high fertilizer treatments, $\mathrm{NO}_{3}-\mathrm{N}$ loss accounted from 3.9 to $42.3 \%$ of the applied N (Table 2). And $\mathrm{NO}_{3}-\mathrm{N}$ loss as a percentage of $\mathrm{N}$ input of $\mathrm{SA}$ treatment was statistically greater than that of FD. However, $\mathrm{NH}_{4}-\mathrm{N}$ loss accounted from 0.06 to $0.95 \%$ of the applied $\mathrm{N}$, those were less than $1 \%$.

These results showed that the saturated flow could make an important contribution to total chemical transport, which was similar to the results of P loss of Gburek and Sharpley studied in 1998 [11], and Zheng et al. [10]. However, it was opposite to the results of Fisher and Healy [8], which showed that the time of the year at which chemicals are applied may be important for chemical transport through the unsaturated zone. And the results of this study also showed that $\mathrm{NO}_{3}-\mathrm{N}$ loss could be more important for contribution to nitrogen loss than that of $\mathrm{NH}_{4}-\mathrm{N}$.

3.3. Temporal Trends of $\mathrm{NO}_{3}-\mathrm{N}$ and $\mathrm{NH}_{4}-\mathrm{N}$ Concentrations. Under the FD treatment, the $\mathrm{NO}_{3}-\mathrm{N}$ concentrations in runoff changed little as time progressed for all fertilizer treatments tested, and it was less pronounced than that 


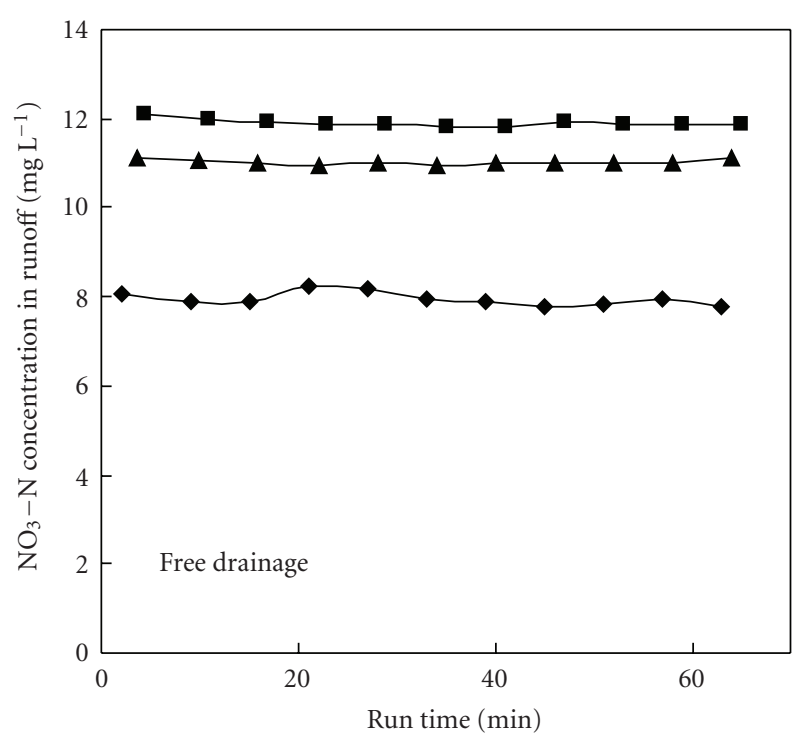

(a)

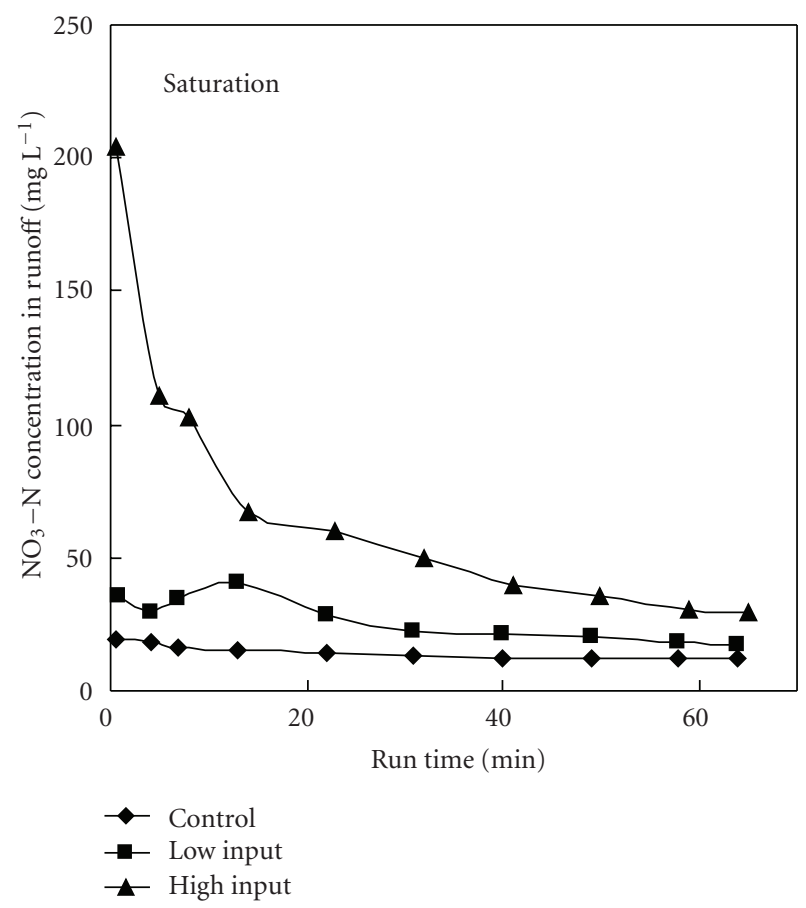

(b)

Figure 2: The $\mathrm{NO}_{3}-\mathrm{N}$ concentration in runoff under different hydraulic gradients.

of the SA treatments (Figure 2). And the trends of $\mathrm{NO}_{3}-$ $\mathrm{N}$ concentrations in runoff during the run were similar to the means of $\mathrm{NO}_{3}-\mathrm{N}$ concentrations (Table 2). Under the SA treatment, although the temporal trend showed that $\mathrm{NO}_{3}-\mathrm{N}$ concentrations in runoff were greatest in the initial runoff and decreased gradually during the run of high fertilizer input, $\mathrm{NO}_{3}-\mathrm{N}$ concentrations of control and low fertilizer input treatments showed little change. And the total temporal trends of $\mathrm{NO}_{3}-\mathrm{N}$ concentrations in surface runoff

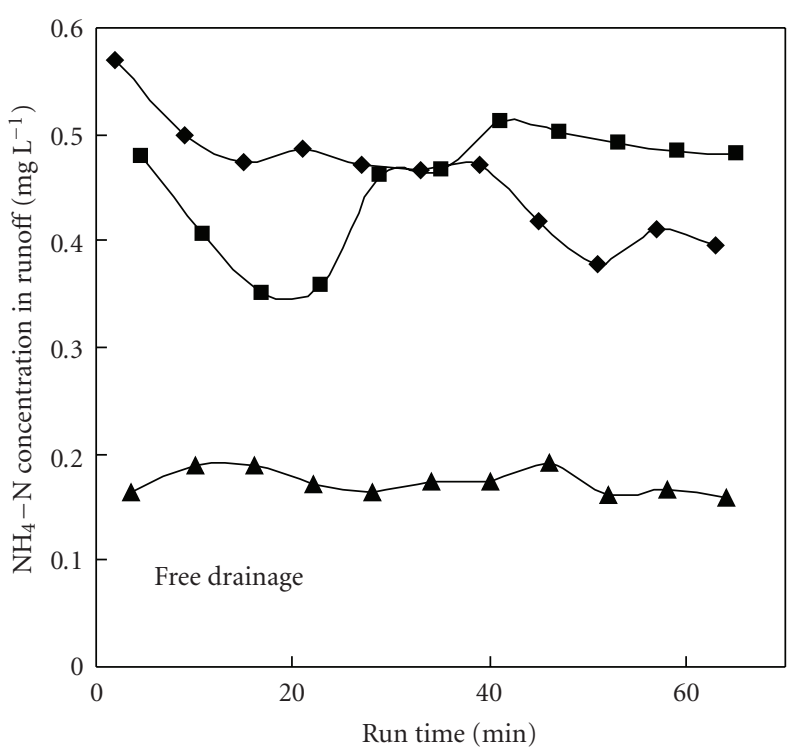

(a)

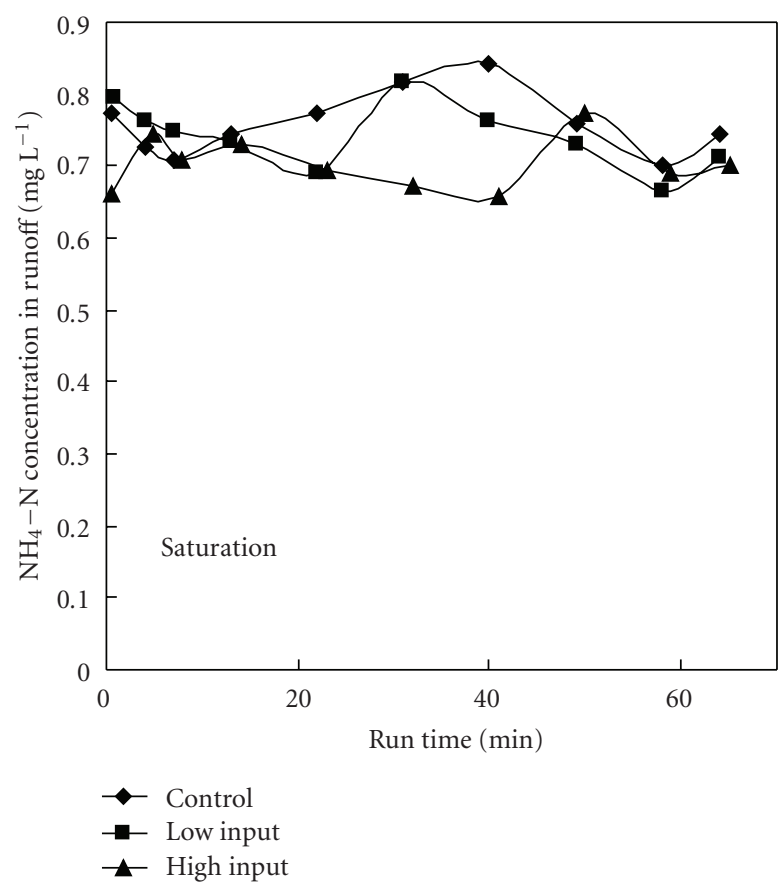

(b)

Figure 3: The $\mathrm{NH}_{4}-\mathrm{N}$ concentration in runoff under different hydraulic gradients

were similar to the results of saturated condition of Zheng et al. [10].

Under the $\mathrm{FD}$ treatment, $\mathrm{NH}_{4}-\mathrm{N}$ concentrations in runoff were greatest in the initial runoff and decreased gradually during the run of control treatment, while $\mathrm{NH}_{4}-\mathrm{N}$ concentrations in runoff of the low fertilizer treatment were greatest in the initial runoff and decreased, then increased gradually (Figure 3). But the $\mathrm{NH}_{4}-\mathrm{N}$ concentrations in runoff of high fertilizer treatment changed little. May be 
those were influenced by runoff progress. Under the SA treatment, the $\mathrm{NH}_{4}-\mathrm{N}$ concentrations in runoff changed little in waves with the entire three fertilizer application rate.

The results of this study indicated that a saturated condition event could cause a severe water quality problem, which is similar to the results reported on P loss by Gburek and Sharpley [11], and $\mathrm{NO}_{3}-\mathrm{N}$ and $\mathrm{P}$ losses by Zheng et al. [10]. And in the saturated condition, compared to control treatment, the concentrations and amount of $\mathrm{NH}_{4}-\mathrm{N}$ of low and high fertilizer treatment were similar; may be the fertilizer rates and denitrification have less effect on loss of $\mathrm{NH}_{4}-\mathrm{N}$ in surface runoff water. While in free drainage condition, compared to topsoil, rapidly available $\mathrm{P}$ and $\mathrm{NH}_{4}-$ $\mathrm{N}$ in eroded sediment were enriched in the Loess Plateau of China [21], and artificial rainfall experiment results also showed that the amount of $\mathrm{NH}_{4}-\mathrm{N}$ losses in surface runoff water increased with the fertilizer rate increasing [14]. So it would be necessary to study extensively on $\mathrm{NH}_{4}-\mathrm{N}$ loss in surface runoff and sediment.

\section{Conclusions}

This paper presents a laboratory study of near-surface hydraulic gradient effects on losses of $\mathrm{NO}_{3}-\mathrm{N}$ and $\mathrm{NH}_{4}-\mathrm{N}$ in surface water under a simulated rainstorm. The results showed a significant increase of $\mathrm{NO}_{3}-\mathrm{N}$ and $\mathrm{NH}_{4}-\mathrm{N}$ transport or losses in surface runoff water under the saturated condition. These results demonstrate the importance of understanding watershed hydrology and its temporal patterns in predicting areas of high chemical loading potential and also showed that the saturated condition can cause greater chemical transport than that of the free drainage condition. The results show that $\mathrm{NO}_{3}-\mathrm{N}$ losses in saturated condition could make a significant contribution to water quality problems.

The results of this study also showed that nitrogen loss formed with $\mathrm{NO}_{3}-\mathrm{N}$ is dominant during the event, but not $\mathrm{NH}_{4}-\mathrm{N}$. However, under FD treatment, $\mathrm{NH}_{4}-\mathrm{N}$ concentrations in runoff water from high fertilizer input were statistically smaller than those from control input and low fertilizer input without $\mathrm{NH}_{4}-\mathrm{N}$ fertilizer input, and it also showed denitrification had less effect on loss of $\mathrm{NH}_{4}-\mathrm{N}$ in surface runoff water in SA treatment. The trend of $\mathrm{NH}_{4}-\mathrm{N}$ loss should be studied more and deeply in the future because of its toxicity to fish, and the rates of fertilizer formed with $\mathrm{NH}_{4}-\mathrm{N}$ should be determined for agriculture during rain season.

Although many studies have been made to determine factors contributing to $\mathrm{N}$ loss, especially the effects of nearsurface hydraulic gradient have been quantified. Incorporating the basic understanding of hydraulic factors and $\mathrm{NH}_{4}-$ $\mathrm{N}$ transport may contribute to control chemical transport to water and minimize water quality problems.

\section{Acknowledgments}

This study was supported by National Basic Research Program of China (Grant no. 2007CB407201), Western Action
Program of the Chinese Academy of Sciences (Second Stage) (Grant No. KZCX2-XB2-05-03), and Innovation Team Plan of Northwest A \& F University (Grant no. 01140202). The authors would thank the editor, Josiane Nikiema, and reviewers, whose comments significantly improved the paper. Especially the authors would thank Professor Don G. Bullock and agronomist Robert E. Dunker works at Department of Crop Science, College of Agricultural, Consumer, and Environmental Sciences at University of Illinois, whose suggestions greatly improved the English writing and quality of the paper. Zhang Yu-bin and Zheng Fen-li contributed equally to this work.

\section{References}

[1] L. West, "World Water Day: A Billion People Worldwide Lack Safe Drinking Water," 2006, http://environment .about.com/od/environmentalevents/a/waterdayqa.htm.

[2] "Ministry of Environmental Protection (MEP), the People's Republic of China. 2009. National environmental statistic bulletin of China," 2009, http://zls.mep.gov.cn/hjtj/qghjtjgb/ 200909/t20090928_161740.htm.

[3] "The National Water Quality Inventory: Report to Congress for the 2002 Reporting Cycle-A Profile," Tech. Rep. Fact Sheet No. EPA 841-F-07-003, United States Environmental Protection Agency (EPA), Washington, DC, USA, October 2007.

[4] S. B. Lovejoy, J. G. Lee, T. O. Randhir, and B. A. Engel, "Research needs for water quality management in the 21st century: a spatial decision support system," Journal of Soil and Water Conservation, vol. 52, no. 1, pp. 19-23, 1997.

[5] A. N. Sharpley, B. H. Foy, and P. J. A. Withers, "Practical and innovative measures for the control of agricultural phosphorus losses to water: an overview," Journal of Environmental Quality, vol. 29, no. 1, pp. 1-9, 2000.

[6] N. C. Brady and R. R. Weil, The Nature and Properties of Soil (Pearson International Edition), Pearson Prentice Hall, Englewood Cliffs, NJ, USA, 14th edition, 2008.

[7] J.-K. Böhlke, "Groundwater recharge and agricultural contamination," Hydrogeology Journal, vol. 10, no. 1, pp. 153-179, 2002.

[8] L. H. Fisher and R. W. Healy, "Water movement within the unsaturated zone in four agricultural areas of the United States," Journal of Environmental Quality, vol. 37, no. 3, pp. 1051-1063, 2008.

[9] C.-H. Huang and J. M. Laflen, "Seepage and soil erosion for a clay loam soil," Soil Science Society of America Journal, vol. 60, no. 2, pp. 408-416, 1996.

[10] F.-L. Zheng, C.-H. Huang, and L. D. Norton, "Effects of nearsurface hydraulic gradients on nitrate and phosphorus losses in surface runoff," Journal of Environmental Quality, vol. 33, no. 6, pp. 2174-2182, 2004.

[11] W. J. Gburek and A. N. Sharpley, "Hydrologic controls on phosphorus loss from upland agricultural watersheds," Journal of Environmental Quality, vol. 27, no. 2, pp. 267-277, 1998.

[12] W. J. Gburek, A. N. Sharpley, L. Heathwaite, and G. J. Folmar, "Phosphorus management at the watershed scale: a modification of the phosphorus index," Journal of Environmental Quality, vol. 29, no. 1, pp. 130-144, 2000.

[13] Y. B. Zhang, Effects of near-surface soil and water conditions on soil erosion process and agricultural non-point source pollutant 
transport at hillslopes, Doctor's degree thesis, Graduate School of Chinese Academy of Sciences, Beijing, China, 2006.

[14] Y.-B. Zhang, F.-L. Zheng, and M. Wu, "Research progresses in agricultural non-point source pollution caused by soil erosion," Advances in Water Science, vol. 18, no. 1, pp. 123132, 2007 (Chinese).

[15] Y.-B. Zhang, F.-L. Zheng, and N. Cao, "Effects of nearsurface soil water conditions on agricultural non-point source pollutant transport," Environmental Science, vol. 30, no. 2, pp. 376-383, 2009 (Chinese).

[16] P. H. Zhou, X. D. Zhang, and K. L. Tang, "Rainfall installation of simulated soil erosion experiment hall of the State Key Laboratory of Soil Erosion and Dryland Farming on Loess Plateau," Bulletin of Soil and Water Conservation, vol. 20, no. 4, pp. 27-30, 2000 (Chinese).

[17] D. H. Pote, T. C. Daniel, A. N. Sharpley, P. A. Moore Jr., D. R. Edwards, and D. J. Nichols, "Relating extractable soil phosphorus to phosphorus losses in runoff," Soil Science Society of America Journal, vol. 60, no. 3, pp. 855-859, 1996.

[18] W. Z. Wang, "Study on the relations between rainfall characteristics and loss of soil in the Loess Plateau: II," Bulletin of Soil and Water Conservation, vol. 3, no. 5, pp. 62-64, 1983 (Chinese).

[19] W. Z. Wang, "Study on the relations between rainfall characteristics and loss of soil in the Loess Plateau: III," Bulletin of Soil and Water Conservation, vol. 4, no. 2, pp. 58-62, 1984 (Chinese).

[20] A. N. Sharpley, S. J. Smith, J. R. Williams, O. R. Jones, and G. A. Coleman, "Water quality impacts associated with sorghum culture in the Southern Plains," Journal of Environmental Quality, vol. 20, no. 1, pp. 239-244, 1991.

[21] F.-L. Zheng, "Effects of accelerated soil erosion on soil nutrient loss after deforestation on the Loess Plateau," Pedosphere, vol. 15, no. 6, pp. 707-715, 2005. 

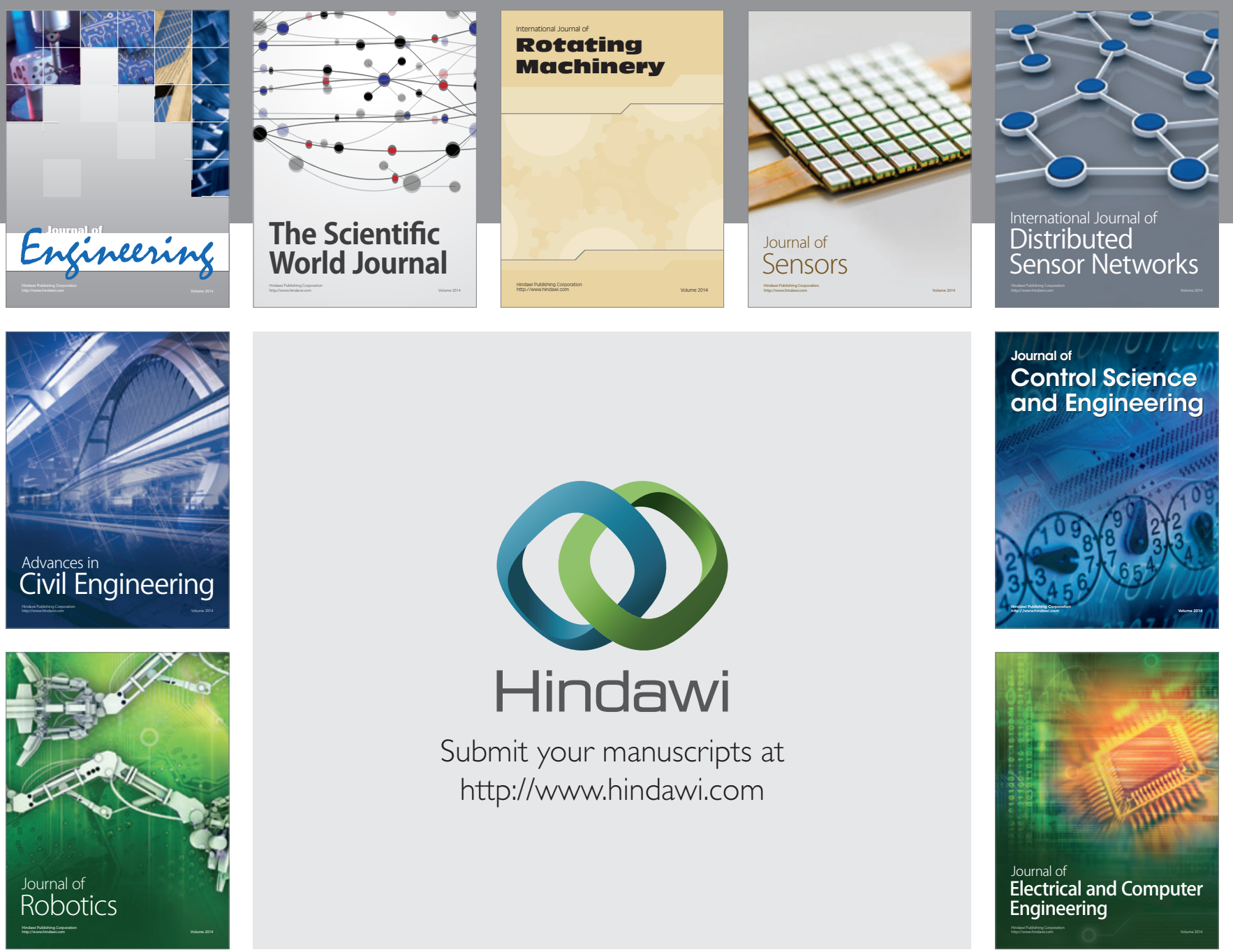

Submit your manuscripts at

http://www.hindawi.com
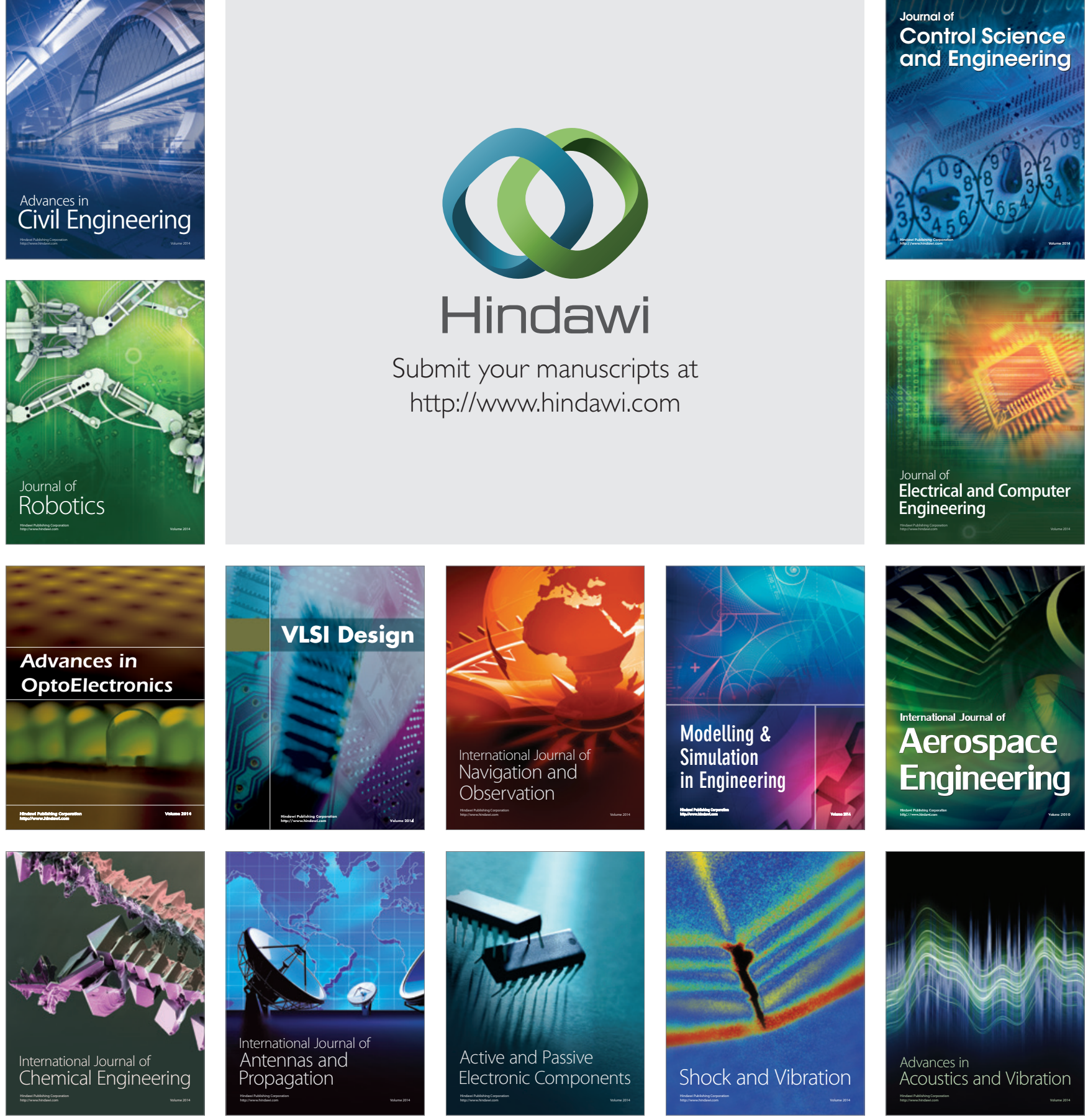